\title{
Obtaining organic dairy products using common thyme as antibiotic replacing therapy of endometritis in cows
}

\author{
Natalia Yarovan ${ }^{1}$, Elena Bondarenko ${ }^{2}$, Alexey Sergachev ${ }^{1}$, Olga Boytsova ${ }^{3}$, Galina Ryzhkova ${ }^{4}$ \\ ${ }^{1}$ Orel State Agrarian University, \\ 69, General Rodina str., Orel, 302019, Russia \\ ${ }^{2}$ Oryol branch of "Central Scientific and Methodological Veterinary Laboratory", \\ 18, Novosilskoe sh., Orel, 302031, Russia \\ ${ }^{3}$ LLC "MedLine", \\ 96, Dubrovinsky Emb, Orel, 302030, Russia \\ ${ }^{4}$ Kursk State Agricultural Academy \\ 70, Karl Marx St., Kursk, 305021, Russia
}

\begin{abstract}
According to the Federal Law of August 3, 2018 No. 280-FZ organic agriculture is referred to as total economic activity that enables the development of ways, methods and technologies that promote favorable state of the environment and improve human health. The need for this law is dictated by the data of the Research Institute of Nutrition of the Russian Academy of Sciences, which claim that $30-50 \%$ of all diseases of Russians arise from the consumption of poor-quality food. $30 \%$ of the pollution of the world ecosystem refer to an agricultural sector, which is an obvious need for the greening of agriculture and the production of organic products. Organic products mean environmentally friendly agricultural products, raw materials and food in the production of which the following requirements are met: the use of agrochemicals is prohibited, pesticides and antibiotics, growth stimulants are absent, and hormones are not used in animal fattening. Taking into account Russian legislation, the products of dairy cattle breeding should not indicate the presence of oxytetrocycline, levomycetine, streptomycin, tetracycline, ampicillin, penicillin, grisin, bacitrocin. Natural resistance in cows is reduced as a result of negative factors (stress factors) characterizing the industrial technology for the production of livestock products itself, and negative environmental factors. Currently, the development of dairy cattle breeding and the increase in animal productivity are restrained by the high incidence of diseases of the reproductive organs, among which a significant part are inflammatory diseases of the genitals, in particular endometritis (up to $90 \%$ of the total number of calving cows). The use of herbal preparations in folk and traditional veterinary science and medicine makes it relevant to search for new plants for obtaining medicinal raw materials in the treatment and prevention of endometritis. Common thyme is proposed as such. The article shows the results of using common thyme for cows with endometritis as antibiotic replacement therapy, which confirmed by an increase in a number of biochemical blood indicators and the overall health of animals.

Key words: organic products, antibiotic replacement therapy, common thyme, postnatal endometritis.
\end{abstract}

\section{Introduction}

Substantial assistance in the agricultural industry is rendered by the state policy of the Russian Federation, which allows to ensure food security of the country, to make useful and safe agricultural products, to support and keep health of the nation, to increase welfare of the people.

By intensive industrial agricultural production enormous economic damage is caused to both the world economy, and the economy of Russia (about 3 billion rubles for 1 year.). Special harm is done to the soil in which pesticides and herbicides which biological activity remains for a long time concentrate in a large number. The fertility of the soil and its environmental friendliness can be supported, using only organic fertilizers (manure, compost, stubble) and also bone meal and minerals as mineral fertilizing; pest control should be carried out by means of their natural enemies; weed control by a crop rotation taking into account a cycle of development and depth of covering of weed seeds. The organic livestock production is characterized by refusal of stable maintenance, refusal of the use of synthetic feed additives and also to exclusion of hormonal medicines and antibiotics [6].

Organic products are considered as environmentally friendly agricultural products, raw materials and food in production of which the following requirements are fulfilled: use of agrochemicals is forbidden, no pesticides and antibiotics, growth stimulants are applied, and in sagination of animals hormonal medicines are not used,

\footnotetext{
* Corresponding author:nii@yandex.ru
} 
transplantation of embryos, cloning and methods of genetic engineering, the gene engineering modified and transgenic organisms are forbidden and also hydroponic methods of cultivation of plants, use of ionizing radiation, packing with use of polyvinylchloride are forbidden [4].

On January 1, 2020 the Federal Law of August 3, 2018 No. 280-FZ [11] came into force. This law presumes organic agriculture as total economic activity that enables the development of ways, methods and technologies which ensure favorable state of the environment and improve human health. Need of this law is dictated by the data of the Research Institute of Nutrition of RAS which claim that $30-50 \%$ of all diseases of Russians arise from the consumption of lowquality food [8]. $30 \%$ of pollution of the world ecosystem fall on the agrarian sector which causes obvious need of the greening of agriculture and production of organic products.

Taking into account Russian legislation, the products of dairy cattle breeding should not indicate the presence of oxytetrocycline, levomycetine, streptomycin, tetracycline, ampicillin, penicillin, grisin, bacitrocin.

In Russia "Sanitary and epidemiologic rules and standards, Hygienic requirements of safety and nutrition value of foodstuff (SanPin 2.3.2.1078-01)" regulating the standards of the content of a number antibiotics both in raw materials, and in animal products are used [9].

The World Health Organization since 2000 imposed the ban on application in livestock production of antibacterial means which are applied to treatment of people. In Russia the ban on use of antibiotics in feed is not imposed, their use is tried to be controlled to ensure people safety of products. Potentially dangerous medicines have to be contained in livestock products lower than the level established by the legislation.

In spite of the fact that in the European Union a ban on the application of antibiotics in feed is imposed, practically in all compound feeds received from the foreign companies the content of various antimicrobial preparations accelerating growth of the animals, reducing the coefficient of conversion of forages and reducing sagination terms is revealed. However the presence of antibiotics in accompanying certificates is not specified [8]. Even residual quantities of antibiotics in compound feeds are capable to cause and cause various pathologies in animals, and as a result violations in the bodies of the people using products from these animals.

Recently increase in antibiotic resistant pathogenic microorganisms is noted that caused decrease in positive effects in treating animals with antimicrobial antibiotics. The mechanism of therapeutic effect of application of antibiotics is based on the oppression of metabolic processes in the agent of an infectious disease. Blocking of metabolism is carried out by linking of an antibiotic with structural formations of a target cell which can be a cell wall, ribosomes and even the genetic apparatus of the infectious agent [8]. Mass and chaotic application of antibiotics in livestock production create favorable conditions in order for evolution of pathogenicity and virulence of agents to proceed quickly which promotes the formation in these microorganisms resistance to antibiotics.

Many fatal diseases for a long time successfully were recovered with antibiotics. Later antibiotics were added to a forage and it became clear that the efficiency of therapeutic effect of these medicines sharply decreased not only in animals, but in humans as well. At the same time microflora both in animals and in humans was broken. It is established that natural growth stimulants and adaptogens are a promising direction of replacing antibiotics [1]. The immune system is a complex multicomponent system highly sensitive to various factors. In industrial technology of managing livestock production a significant growth of morbidity is connected with the violation of the immunity which is followed by violations in the immune regulatory processes [1].

Antibiotics are actively used in livestock production, they are used in $50 \%$ of world production, i.e. in $70 \%$ of the developed countries [10]. Now the therapeutic potential of antibiotics is exhausted and the phenomenon of resistance to antibiotics extends that is considered as threat of human insusceptibility of these means. In this regard many states either completely refused them (except urgent need of medical application), or control their content in livestock products strictly. Due to above told there is a high relevance of development of alternative means and ways for decrease or a complete elimination of antibiotics in agriculture. In Russia the search of the means replacing fodder antibiotics in livestock production and poultry farming is actively conducted. A real step to such replacement is use of means on the basis of vegetable raw materials.

The natural resistance at cows decreases as a result of influence of the negative factors (stress factors) characterizing the industrial production technology of livestock products, and negative factors of the environment [1.3].

In this regard now development of dairy cattle breeding and increase in efficiency of animals restrain the high frequency of diseases of bodies of reproduction among which a considerable part is occupied by inflammatory diseases of genitals, in particular, endometritises (up to $90 \%$ of all livestock of the calved cows), inclined to long course and development weed system frustration. This fact demands the comprehensive and weighed approach to the choice of recovery treatment, relying on wide use of the non-drug methods promoting increase in own protective reactions of an organism.

Use of vegetable medicines in national and traditional veterinary science and medicine do relevant search of new plants for receiving medicinal raw materials for treatment and prevention of an endometritis. As that thyme common is offered.

It is known that thyme common contains a complex of biologically active compounds: thymol, carvacrol, borneol, cymene, pinene, linalrol, tanning matter, bitter stuff, mineral salts, gum, ursolic and oleic acids, triterpenes, flavonoids, saponins, tannins, vitamin $\mathrm{C}$, calcium, magnesium, potassium and other substances. The antioxidant activity of thyme is attributed to its 
phenolic structure and is explained by its oxidationreduction properties which play an important role in adsorption and neutralization of free radicals or decomposition of peroxides [5,7, 12, 14].

The studies conducted by N.I. Yarovan, and O.A. Boitsova confirm the anti-free radical activity of thyme common [2, 13]. As the main pathogenetic mechanism of development of destructive violations of cellular membranes of uterus tissues in case of sharp endometritis pathological growth of free radical (peroxide) oxidation of lipids which is not compensated by their own antioxidant system is considered. It is followed by the expressed morphological changes of cells of endometrium that is caused by the increased content of products of peroxide oxidation and their influence on cellular membranes, at the same time protective and compensatory mechanisms of an antioxidant system are exhausted. Use as antibiotic replacing therapy of means based on thyme common which possess anti-free radical and membrane stabilizing action promotes decrease in destructive changes of membranes in the bodies of the cows sick with endometritis, having positive impact on course and an outcome of a disease. Inhibiting influence of thyme common on free radical oxidation is confirmed by decrease in blood serum of cows.

The purpose of the research was studying therapeutic efficiency of thyme common as in antibiotic replacing therapy of endometritis in cows.

The assessment of pharmaco-therapeutic efficiency of thyme common was carried out by the concentration of malonic dialdehyde (MDA), ceruloplasmin (CP), cholesterol (CS), triglycerides (TG), HDL, LDL, VLDL, by glucose, total protein, urea, creatinine, bilirubin. The condition of an antioxidant system was determined by activity of ceruloplasmin $90 \%$ of which contains in blood.

Reduction of inflammatory process in endometrium was confirmed by biochemical indicators: the level of glucose, total protein, urea, creatinine, bilirubin. And also in the animals receiving thyme normalized morphology of the damaged tissues and involution of organic violations in a uterus is noted.

The conducted studies showed that application of thyme common as a means in antibiotic replacing therapy has significant anti-inflammatory effect in sharp endometritis in cows. The received results allow to consider that the basic mechanism causing positive effect of thyme in antibiotic replacing therapy, in inflammatory diseases of a uterus is its ability to oppress or inactivate processes of free radical oxidation of lipids that is caused by existence of the biologically active compounds which are contained in a test plant.

The analysis of biochemical studies of blood serum of cows ill with postnatal endometritises showed significant changes in cows in proteinous exchange, carbohydrate, lipidic and acid-base balance. The onset of the illness is characterized by a decrease in the total protein and albumine and improvement of the level of beta and gamma globulins that characterizes immunological reorganization of an organism. The increase in the level of sugar in the blood indicates the high level of bioenergy expenses. The inflammatory process is confirmed also by the accumulation of sour products of exchange, i.e. acidosis.

There are various methods based on the use of pharmacological preparations of synthetic and plant origin, including also antibiotics, in treating postnatal endometritises that is not admissible for receiving organic dairy products (A.S. Yemelyanova, E.I. Lupova, 2012).

In our opinion the use of thyme common as a means of prophylaxis and therapy is of special interest in postpuerperal endometritis of cows.

\section{Materials and methods}

The research consisted of two series of experiments. In the first series, milk and dairy products were analyzed for the content of antibiotics; in the second one, an experimental method was used to find a means for antibiotic replacement therapy. Determination of the content of antibiotics in dairy products (drinking milk, condensed milk, cheese was carried out with the help of an analytical complex based on a liquid chromatography-mass spectrometer). Our studies on the content of antibiotics in dairy products obtained from dairy enterprises of Orel Region showed the presence of a small number of antibiotics tylosin, clindamycin, sulfaquinoxalin, which made it necessary to find means and develop methods of antibiotic replacement therapy for obtaining organic dairy products in the treatment of postnatal endometritis in cows.

Scientific research was carried out in the farms of the Orel Region in JSC "AGRO-INDUSTRIAL COMPLEX "ORLOVSKAYA NIVA" and in "MASLOVO LLC". Common thyme was used as a means of antibiotic replacement therapy for the treatment of postnatal endometritis in cows.

\section{Results and Discussion}

We formed a group of cows with post-puerperal endometritis in the amount of 10 heads.

Common thyme was added to the diet of cows at a rate of $15 \mathrm{~g}$ per $100 \mathrm{~kg}$ of live weight of the cow.

Blood for experiments was taken in the morning, before feeding the cows, from the jugular vein before the experiment, and then on the 14th and 28th days of the experiment.

In studying the adaptation processes that occur under the conditions of endometritis, more and more researchers study the processes of lipid peroxidation, since the strengthening of this oxidation is a non-specific characteristic of body stress, and therefore the development of any pathology, including endometritis.

In the course of our experiment, the following changes in the oxidant-antioxidant system (MDA and $\mathrm{CP}$ ) values were established in the cows of experimental groups with endometritis treated with common thyme in addition to the main diet (Table 1). 
Table 1. Changes in the oxidant-antioxidant system values in cows treated with common thyme

\begin{tabular}{|c|c|c|c|c|c|}
\hline Indi-cators & \multirow{2}{*}{$\begin{array}{c}\text { Ani- } \\
\text { mal } \\
\text { Group }\end{array}$} & $\begin{array}{c}\text { Refe- } \\
\text { rence } \\
\text { Values }\end{array}$ & $\begin{array}{c}\text { before the } \\
\text { experi- } \\
\text { ment }\end{array}$ & 14th day & 28th day \\
\hline $\begin{array}{c}\text { MDA, } \\
\mathrm{mmol} / 1\end{array}$ & $\begin{array}{c}\text { main } \\
\text { diet+ } \\
\text { thyme } \\
(\mathrm{MD}+\mathrm{T})\end{array}$ & $\begin{array}{c}0,27- \\
0,35\end{array}$ & $\begin{array}{c}0,75 \\
\pm 0,030^{* *}\end{array}$ & $\begin{array}{c}0,58 \\
\pm 0,033^{*}\end{array}$ & $\begin{array}{c}0,46 \\
\pm 0,032^{*}\end{array}$ \\
\hline $\begin{array}{c}\mathrm{CP}, \\
\mathrm{mmol} / 1\end{array}$ & $\mathrm{MD}+\mathrm{T}$ & $1,84-2,3$ & $\begin{array}{c}1,27 \\
\pm 0,48^{*}\end{array}$ & $\begin{array}{c}1,47 \\
\pm 0,050^{*}\end{array}$ & $\begin{array}{c}1,67 \\
\pm 0,020^{* *}\end{array}$ \\
\hline
\end{tabular}

Note: reliable changes in comparison with control group $*$ at $\mathrm{P}<0.05 ; * * \mathrm{P}<0.01 ; * * * \mathrm{P}<0.001$

Analysis of tabular data showed that on the 14th and 28th day of the experiment, the serum MDA level of common thyme-treated cows was lower than that of animals relative to the start of the experiment by 0.17 $\mathrm{mmol} / \mathrm{l}(\mathrm{P}<0.05)$ and $0.29 \mathrm{mmol} / \mathrm{l}(\mathrm{P}<0.05)$, respectively. In parallel with the decrease in MDA content, an increase in ceruloplasmin activity by 0.20 $\mathrm{mmol} / \mathrm{L}(\mathrm{P}<0.05)$ and $0.40 \mathrm{mmol} / \mathrm{L}(\mathrm{P}<0.001)$ was found in animals treated with thyme grass.

Blood serum lipid profile indices of highly productive cows with endometritis using common thyme as adaptogens in feeding are shown in Table 2.

Table 2. Characteristics of blood serum lipid profile of common thyme fed cows with endometritis

\begin{tabular}{|c|c|c|c|c|c|}
\hline \multirow{2}{*}{ Indicators } & \multirow{2}{*}{\begin{tabular}{|l|} 
Animal \\
Group
\end{tabular}} & \multirow{2}{*}{$\begin{array}{l}\text { Referenc } \\
\text { e Values }\end{array}$} & \multicolumn{3}{|c|}{ Experiment Days } \\
\hline & & & $\begin{array}{l}\text { before } \\
\text { the } \\
\text { beginnin } \\
\text { g of } \\
\text { feeding }\end{array}$ & 14th day & 28th day \\
\hline $\mathrm{CS}, \mathrm{mmol} / \mathrm{l}$ & $\mathrm{MD}+\mathrm{T}$ & $1,3-4,42$ & $5,2 \pm 0,14$ & $\begin{array}{l}4,82 \pm \\
0,136\end{array}$ & $\begin{array}{l}4,64 \pm \\
0,109\end{array}$ \\
\hline $\mathrm{TG}, \mathrm{mmol} / \mathrm{l}$ & $\mathrm{MD}+\mathrm{T}$ & $0,22-0,60$ & $\begin{array}{l}0,98 \pm \\
0,051\end{array}$ & $\begin{array}{l}0,82 \pm \\
0,043\end{array}$ & $\begin{array}{l}0,77 \pm \\
0,041\end{array}$ \\
\hline HDL, unit & $\mathrm{MD}+\mathrm{T}$ & $0,8-1,7$ & $\begin{array}{l}0,57 \pm \\
0,010\end{array}$ & $\begin{array}{c}0,646 \pm \\
0,02\end{array}$ & $\begin{array}{c}0,705 \pm \\
0,016\end{array}$ \\
\hline LDL, unit & $\mathrm{MD}+\mathrm{T}$ & $2,0-4,0$ & $\begin{array}{l}4,75 \pm \\
0,085\end{array}$ & $\begin{array}{c}4,359 \pm \\
0,066^{* *}\end{array}$ & $\begin{array}{c}4,011 \pm \\
0,101 * * *\end{array}$ \\
\hline VLDL, unit & t $\mathrm{MD}+\mathrm{T}$ & $0,3-0,9$ & $\begin{array}{l}0,98 \pm \\
0,016\end{array}$ & $\begin{array}{c}0,940 \pm \\
0,012\end{array}$ & $\begin{array}{c}0,928 \pm \\
0,022\end{array}$ \\
\hline
\end{tabular}

In the analysis of serum lipids, it was found that in cows of experimental groups on the 14th day of the experiment, the cholesterol content was lower compared to the beginning of the experiment by $0.38 \mathrm{mmol} / \mathrm{l}$, triglycerides by $0.16 \mathrm{mmol} / \mathrm{l}$, LDL by 0.40 units. $(\mathrm{P}<$ $0.001)$, VLDL - by 0.04 units, HDL - by 0.40 units, relative to the beginning of the experiment. On day 28 , cholesterol decreased by $0.56 \mathrm{mmol} / \mathrm{l}$; triglycerides by $0.21 \mathrm{mmol} / \mathrm{l}$; LDL by 0.74 units. $(\mathrm{P}<0.001)$; VLDL - by 0.06 units, HDL increased by 0.14 units. 3.

Other biochemical blood values are shown in Table

Table 3. Biochemical values of blood serum of cows with endometritis when common thyme was used as adaptogen in feeding

\begin{tabular}{|c|c|c|c|c|c|}
\hline Indicators & $\begin{array}{l}\text { Animal } \\
\text { Group }\end{array}$ & $\begin{array}{c}\text { Reference } \\
\text { Values }\end{array}$ & $\begin{array}{c}\text { Before } \\
\text { feeding } \\
\text { start }\end{array}$ & 14th day & 28th day \\
\hline $\begin{array}{l}\text { Glucose, } \\
\mathrm{mmol} / \mathrm{l} \\
\end{array}$ & $\mathrm{MD}+\mathrm{T}$ & $2,22-3,3$ & $\begin{array}{l}2,29 \pm \\
0,118 \\
\end{array}$ & $\begin{array}{l}2,64 \pm \\
0,086\end{array}$ & $\begin{array}{l}2,74 \pm \\
0,086\end{array}$ \\
\hline $\begin{array}{l}\text { Total } \\
\text { protein, g/l }\end{array}$ & $\mathrm{MD}+\mathrm{T}$ & $72-86$ & $\begin{array}{c}70,88 \pm \\
0,560\end{array}$ & $\begin{array}{c}73,11 \pm \\
0,75^{*}\end{array}$ & $\begin{array}{c}74,18 \pm \\
1,021^{* *}\end{array}$ \\
\hline $\begin{array}{l}\text { Urea, } \\
\mathrm{mmol} / \mathrm{l}\end{array}$ & $\mathrm{MD}+\mathrm{T}$ & $3,3-6,7$ & $\begin{array}{l}3,81 \pm \\
0,253\end{array}$ & $\begin{array}{l}3,65 \pm \\
0,126\end{array}$ & $\begin{array}{l}3,52 \pm \\
0,161\end{array}$ \\
\hline $\begin{array}{l}\text { Creatinin, } \\
\mathrm{mmol} / \mathrm{l}\end{array}$ & $\mathrm{MD}+\mathrm{T}$ & $40-90$ & $\begin{array}{l}82,7 \pm \\
2,984\end{array}$ & $\begin{array}{c}79,1 \pm \\
3,89\end{array}$ & $\begin{array}{c}76,45 \pm \\
4,381\end{array}$ \\
\hline $\begin{array}{l}\text { Bilinubin, } \\
\mathrm{mmol} / \mathrm{l}\end{array}$ & $\mathrm{MD}+\mathrm{T}$ & $0,2-5,1$ & $\begin{array}{l}5,02 \pm \\
0,034\end{array}$ & $\begin{array}{c}4,64 \pm \\
0,11 * *\end{array}$ & $\begin{array}{c}4,36 \pm \\
0,121 * *\end{array}$ \\
\hline
\end{tabular}

Note: reliable changes in comparison with control group

$*$ at $\mathrm{P}<0.05 ; * * \mathrm{P}<0.01 ; * * * \mathrm{P}<0.001$

We have identified changes in a number of other biochemical indicators (Table 3). On the 14th day of the experiment, it was found that cows with endometritis showed an increase in glucose by $0.35 \mathrm{mmol} / \mathrm{l}$; total protein by $2.23 \mathrm{~g} / 1(\mathrm{P}<0.05)$; reduction of urea by 0.16 $\mathrm{mmol} / \mathrm{l}$; creatinine $3.6 \mathrm{mmol} / \mathrm{l}$; bilirubin by $0.38 \mathrm{mmol} / 1$ $(\mathrm{P}<0.01)$ compared to the start of the experiment.

On day 28 , the trend retained, on the 14 th day of the experiment after the use of common thyme in cows with postnatal endometritis the glucose content increased by $0.45 \mathrm{mmol} / \mathrm{l}$, the level of total protein by $3.30 \mathrm{~g} / \mathrm{l}(\mathrm{P}<$ $0.01)$, the concentration of urea decreased by 0.29 $\mathrm{mmol} / \mathrm{l}$, creatinine by $6.25 \mathrm{mmol} / \mathrm{l}(\mathrm{P}<0.01)$, bilirubin by $0.66 \mathrm{mmol} / 1(\mathrm{P}<0.01)$.

\section{Conclusion}

The results of a biochemical blood test in cows with endometritis using common thyme as a corrective agent showed that their value is close to referent, which indicates the process of recovery of cows. The results are correlated with those obtained from antibiotics for cows with postnatal endometritis. However, it is preferable to use plant phytopreparations, in particular common thyme, since when using antibiotics, dairy products cannot be considered organic.

\section{References}

1. M.I. Barashkin, Effect. Anim. Husb., 2 (112) (2015)

2. O.A. Boitsova, N.I. Yarovan, Zootechn., 10 (2013)

3. A.S. Vecherkin, Vet. Sci. 9 (2004)

4. 4. S.A. Goryunova S.A. Production of organic products as a factor in preserving human health In Proc. of the Great International \& Practical Conftrence (2019)

5. A.S. Emelyanova, E.I. Lupova, Bull. FGBOU VPO RG ATU, 4 (2012)

6. L. Yu. Konovalenko, J. VNIIMZH, 3(35) (2019)

7. A.V. Korobov, O.S. Bushukina, M.N. Stebnev,. Medicinal and poisonous plants in veterinary medicine, St. Petersburg: Lan (2007)

8. O.E. Merezhko, N.B. Stanishevskaya, Izvest. Orenburg State Agrar. Univ., 2(52) (2015) 
9. SanPiN 2.3.2.1078-01 Hygienic requirements for food safety and nutritional value

10. A.N. Tunik Vet. Sci., 10 (2007).

11. Federal Law "On Organic Products and on Amending Certain Legislative Acts of the Russian Federation" dated 03.08.2018 N 280-Ф3

12. K.H. Baser, Curr Pharm Des., 14(29) (2008).

13. O.A. Boitsova. Vestnik OrelGAU, 5(44) (2013)

14. W. Zheng, J. Agr. \& Food Chem., 49 (2001) 